\title{
Analysis on Factors Influencing Geography Teachers' Ability in Constructing High-Order Thinking Skills (HOTS) Assessment Instrument
}

\author{
Suhendro Suhendro*, Dede Sugandi, Mamat Ruhimat \\ Department of Geography Education, School of Postgraduate Studies, Universitas Pendidikan \\ Indonesia, J1. Dr. Setiabudhi No. 229, Bandung, 40154, Indonesia
}

Received 17 December 2020/Revised 19 July 2021/Accepted 4 August 2021/Published 28 August 2021

\begin{abstract}
The teacher's ability to construct assessment instruments is a focus that needs to be considered. Furthermore, the demand of the 21 st century directs teachers to set questions that are oriented to train students' abilities in higher-order thinking. However, several factors affect the ability to construct HOTS-oriented assessment instruments. This study aims to investigate what factors influence geography teachers' ability to develop higher-order thinking skills (HOTS) instruments to measure learning outcomes. This study used a survey method with a quantitative approach. The data collection technique was field observation, and multiple linear regression was used for analysis. The results showed the linearity of teacher education regarding the length of teaching geography was 0.904 , the tertiary institution was 0.009 , and the background of education was 0.019. Also, teachers' certification was 0.007 , their training was 0.032 , and their experience in making HOTS questions was 0.047 . The coefficient value of determination $\mathrm{R}$, namely 0.635 means the relationship between teaching length, the linearity of their education in tertiary institutions, background, certification, training, and experience regarding the ability to develop HOTSoriented assessment instruments is $63.5 \%$. This means the relationship is strong, and $36.5 \%$ is another factor. This study concludes that the factors that significantly affect the ability of geography teachers in developing HOTS-oriented assessment instruments are the linearity factor of teacher education in universities, education background, certification, teacher training and experience in making HOTS questions.
\end{abstract}

Keywords: Teacher ability factors; Assessment; Higher-order thinking skills

\section{Introduction}

Countries are investing in education with the hope of developing their economy and long-term well-being. The dilemma at present is that although the imperatives in the field of employment have shifted, and education has not changed (Chalkiadaki, 2018). Furthermore, the accelerated evolution of time and globalization needs an enhancement in the standard of education. Adjustments for change and improved results also need to be made in the education sector (Sugandi \& Somantri, 2018).

*Corresponding author:

Email address : suhendrogeografi11@gmail.com (Suhendro Suhendro) 
The trend of education in the 21 st century commonly referred to as the era of knowledge has objectives, namely (1) preparing people in a dynamic and unpredictable world, (2) promoting creative behavior, (3) providing independence for unique individual intelligence, and (4) making innovators. In addition, the direction of sustainable development in Indonesia is the improvement of human resources by improving the quality of education (Astuti et al., 2019).

Fundamentally, effective learning can contribute to good quality learning, which can be seen from the assessment outcomes. A fair assessment will enable educators to recognize good instructional methods and inspire learners to learn more. Therefore, teachers need the ability and skills to carry out assessments following the predetermined standards (Ati et al., 2019). Assessment in the 21 st century is a form of implementing the changing times to achieve the goals of learning. Humans are required to print the quantity and quality of human resources that have superior competitiveness. In this case, the teacher's role is essential to produce excellent human resources through the teaching and learning process. Therefore, to realize educational goals, the process of learning assessment needs to be appropriately designed. One of the realizations of educational goals is how the educator execute the assessment process, be it planning, designing, and development (Suhendro et al., 2020).

In accordance with 21 st century learning instruction and the Era of Industrial Revolution 4.0, it is expected that in learning, the teacher will familiarize students with critical thinking, one of which is through the Higher Order Thinking Skills (HOTS) questions. This will enable the students to be creative, innovative, and compete globally (Jannah \& Ernawati, 2020). In this case, the teacher's role is very important to produce superior human resources through the teaching and learning process (Suhendro et al., 2020).

Today, high-order thinking skills are important in the educational system in Indonesia to increase quality.The Programme for International Student Assessment (OECD, 2019), ranked Indonesia in 74th place, which is sixth from the bottom. In the Science category, Indonesia received a score of 396, far below the OECD average score of 489. Meanwhile, in Mathematics, Indonesia is ranked 7th from the bottom with a score of 379 (OECD average 489). Also, the lowest score was in the Reading category, which was 371 (OECD average 489). Based on the survey results, Indonesia's PISA scores can be improved through highlevel oriented learning and assessment activities.

In line with the 2013 Curriculum implementation, the Ministry of Education and Culture has improved content and assessment standards, focusing on Higher Level Thinking Skills (HOTS) (Kurniawan \& Lestari, 2019). Basically, HOTS are abilities that prepare students and enable them think critically and creatively when they face unknown problems, 
or dilemmas to answer questions. In this situation, they are not only expected to memorize answers but also to solve the problems (King et al., 2011).

In line with the statement above, HOTS is needed not only in handling the revised 2013 curriculum but also in 21 st century learning. By the development and HOTS application in teaching and learning activities, students will have deeper and more critical thinking (Budiastini et al., 2020). Moreover, HOTS-based assessment can (1) increase motivation to learn, and (2) improve learning outcomes (Brookhart, 2010). Meanwhile, in the preparation of HOTS questions, a stimulus is generally used. In this context, the stimulus it presents is contextual and interesting (Fanani, 2018). Related to higher-order thinking assessments, Mohamed \& Lebar (2017) designed an integrated structure regarding the item elements in an assessment to measure HOTS. This can be seen in Figure 1 as follows:

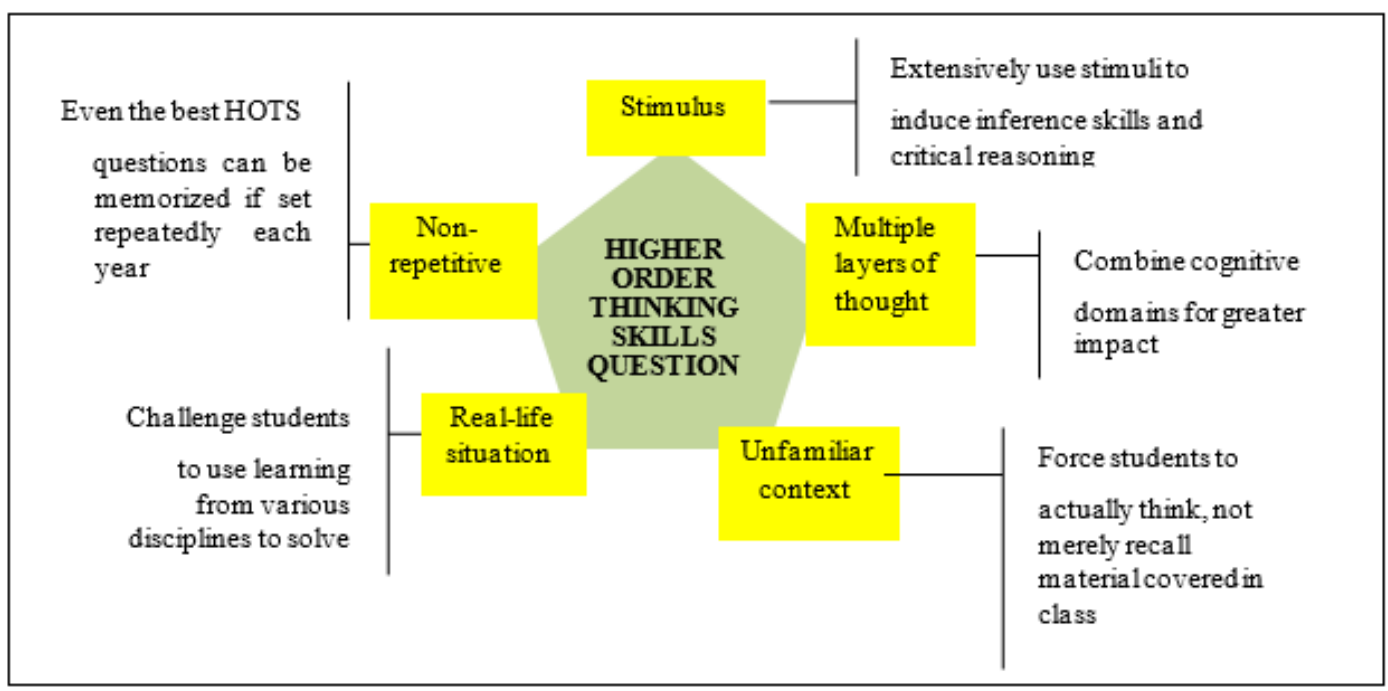

Figure 1. The elements of the assessment items for measuring HOTS (Mohamed \& Lebar, 2017)

In measuring HOTS assessments, students need to form and train their thinking to analyze, evaluate, and create in line with the three HOTS-oriented learning model designs described in the previous sub-section. The HOTS questions are those requiring higher-order thinking skills. Hence, shaping better student quality, questions like this need to be developed and applied in the class. The higher-order thinking skills are divided into four groups, namely problem solving, decision making, as well as critical and creative thinking (Nitko \& Brookhart, 2011).

HOTS is actually introduced to students from an early age, by being accustomed to working on problems that require thinking. The children will get used to solving fairly difficult problems (Utaminingtyas, 2020). Also, the ability to think critically cannot be leveled and forced. The teacher needs to get around this effectively and stimulate the 
reasoning and thinking of students (Budiastini et al., 2020). Heong et al., (2011) showed students use broad thinking to discover new challenges. Also, higher order thinking requires applying further knowledge and information that has been acquired, and manipulating the information to get potential answers in new situations.

Nowadays, an interesting issue to be studied in-depth is related to the ability of teachers to implement HOTS in class, which has become an issue in Indonesian education. Conceptually, the skill or knowledge of teachers is an example of what instructors can do with their works. This is in the form of teaching and learning, habits, and outcomes (Munandar et al., 2020; Suyanto \& Jihad, 2013). One of the factors that influence education success is the ability to conduct and take advantage of assessments, process evaluation, and learning outcomes (Noprinda \& Soleh, 2019). Teachers as professional staff significantly influence learning activities. Therefore, they have a duty and role in helping students develop their potential (Ayuni, 2016).

The existence of teachers as professionals in the field of education has an important role in guiding students to achieve learning goals. One of their main duties is to evaluate learning outcomes (Afrian et al., 2018). Nevertheless, teachers' ability to construct measurement tools and assess learning outcomes still needs to be studied because measurement and evaluation are inseparable parts of the learning process. How could reliable data on students' real abilities or competencies be produced when the measuring instruments used are not reliable (Ruhimat, 2018).This is in line with Wahid's statement which claimedthe teachers stated that they understood HOTS but still experienced difficulties in its implementation (Wangid et al., 2020).

Therefore, human resources are the goals of every nation, which can be achieved through education (Nugroho \& Hastuti, 2019). The current dynamics developing are professional teacher competencies that have an impact in the classroom. Because basically teachers are not only responsible for the transfer of knowledge, but the task of educating students is the most important thing. Hence, the more the teachers' abilities, the more they will produce quality generations for the future (Ikhsan et al., 2017).

Furthermore, the learning outcomes are expected to assist students to develop HOTS because it stimulates broad and deep thinking related to the concept (Hong \& Salika, 2011). Based on the obtained field data regarding the geography teachers' ability to make questions in Lampung Province, it was shown that MOTS still dominated the teacher's ability to make questions with the number of 1976 items out of 3710 . When the percentage reached $53.26 \%$, the dominance can be seen in the questions made by the teacher who is oriented to LOTS with a total of 1431 items from 3710 at $38.57 \%$. Meanwhile, the ability to make HOTS- 
oriented questions was still trapped in a figure of less than $10 \%$, namely only $8.167 \%$, with a total of 303 items from the 3710 analyzed (Field Observation, 2020).

Based on the explanation in the background, it can be concluded that the analysis of teacher's ability to construct questions for classroom learning evaluation shows it is still dominated by MOTS level. A previous study also showed (1) $70 \%$ of the participating teachers comprehensively understand the concept of knowledge concept and dimensions, (2) $60 \%$ have good understanding about higher order thinking, (3) 60\% have a good understanding of HOTS preparation techniques, (4) The number of $50 \%$ of participating teachers is skilled in preparing questions, implementing, and following up on evaluation results (Wantoro et al., 2019).

These statements are supported by Ruhimat (2018) which showed only a small proportion of teacher respondents make questions by referring to the blue-print. Meanwhile, there are even those who do not make blueprints. Also, the test measuring instruments made did not go through the validity and reliability test stages. Teacher respondents have not shown an increase in quality in the development of measuring tools for student learning outcomes (Artvinli, 2017; Suherman, 2019). Furthermore, reports showed geography teachers in the world still have difficulties in various things from how to manage classes to making tools in measuring success in learning. The measuring tools as an instrument in evaluating learning activities are important. The various studies on creating measuring instruments in the world are not different from those in Indonesia, and there are still many teachers who still do not understand how to make good and correct instruments.

Several studies have been reported to describe the teacher's ability to construct HOTS questions. Therefore, this study aims to deeply examine the analysis of the factors that affect the ability of geography teachers to construct questions oriented at the HOTS level. Furthermore, this study aims to identify and analyze the factors of geography teachers that affect their ability to develop learning-oriented outcomes instruments. The higher-order thinking skills (HOTS) include the length of teaching $\left(\mathrm{X}_{1}\right)$, teacher education linearity in tertiary institutions $\left(\mathrm{X}_{2}\right)$, education background $\left(\mathrm{X}_{3}\right)$, certification $\left(\mathrm{X}_{4}\right)$, training $\left(\mathrm{X}_{5}\right)$, and experience in making HOTS questions $\left(\mathrm{X}_{6}\right)$.

\section{Methods}

\subsection{Research Design}

This is a survey study with an emphasis on a quantitative approach. This is because it aims to find data on the characteristics of geography teachers that affect their ability to develop higher-order thinking skills (HOTS)-oriented assessment instruments. 


\subsection{Sampling Technique}

The sampling method was the overall technique of teachers who are in Lampung Province, with a total of 30 at the High School (SMA/MA) level . The reasons for the overall sampling technique in the area include affordable accessibility, a high level of representation, and not too many participants.

\subsection{Data Collection Technique}

The data collection techniques used questionnaires and tests. The questionnaires were used to ascertain the teacher's background and experience in developing HOTS-oriented learning outcomes instruments. These include teaching length, education linearity in universities, educational background, certification, training, and experience in making HOTS questions. Meanwhile, the instrument to measure the ability is to use a test with an analysis of the teacher's ability to write HOTS-oriented questions.

\subsection{Instrument Development}

The development of instruments to determine the ability to make HOTS questions uses several measurement indicators in Table 1.

Table 1. Indicators of teacher ability in making HOTS questions

\section{Measured Variables}

\section{Indicators}

The operational verb used is to distinguish The operational verb used is to organize The operational verb used is to attribute

The operational verb used is to check The operational verb used is to criticize

The operational verb used is to formulate The operational verb used is to plan The operational verb used is to produce

Source: (Anderson \& Krathwohl, 2010)

Based on the indicator, the teacher was asked to make an assessment instrument of 10 items which were subsequently assessed through scoring criteria 1-5. These were juxtaposed with the HOTS-oriented question criteria based on operational verbs at levels of $\mathrm{C} 4$ (analysis), C5 (evaluation), and C6 (creating). 


\subsection{Analysis Technique}

The multiple linear regression was used to examine the factors that affect the ability to develop HOTS-oriented questions. This includes several tests, including the t-test (partial), the $\mathrm{F}$ test, and the determination test coefficient. Also, several tests were conducted using criteria according to Riduwan (2012) describing the following: Very good (Score 5), Good (Score 4), Enough (Score 3), Poor (Score 2), and Very poor (Score 1). The results were then processed with the tabulation of the characteristics of geography teachers with the following indicators, namely (1) Age of Respondents (2) Teaching Background, (3) Linearity of educational background, (4) Educational Background, (5) Training Experiences, and (6) Experiences in making HOTS questions. The next step is data processing using SPPS Statistic 22 by conducting several tests such as t-test (partial), F-test, and coefficient of determination.

\section{Results and Discussion}

In analyzing the characteristic factors that affect the ability to develop HOTS-oriented assessment instruments, there are several factors tested, including teaching length $\left(\mathrm{X}_{1}\right)$, linearity of education in tertiary institutions $\left(\mathrm{X}_{2}\right)$, background $\left(\mathrm{X}_{3}\right)$, certification $\left(\mathrm{X}_{4}\right)$, training $\left(\mathrm{X}_{5}\right)$, and experience in making HOTS questions $\left(\mathrm{X}_{6}\right)$. The following is testing through multiple linear regression:

\subsection{Statistical Testing of T-test (Partial)}

Statistical testing of t-test (partial) in 6 independent variables on 1 dependent is based on decision-making criteria. When the significant value of $t>0.05$, then there is no major influence of independent on the dependent variable. This means accepting $\mathrm{H}_{0}$ and refusing $\mathrm{H}_{1}$. Also, when significant $\mathrm{t}<0.05$, the dependent variable has a significant impact between the independent. This means denying $\mathrm{H}_{0}$ and accepting $\mathrm{H}_{1}$. The processing results using the SPPS application are obtained in Table 2.

Table 2. Statistical testing of t-test partial multiple linear regression

\begin{tabular}{ccccccc}
\hline & & \multicolumn{2}{c}{$\begin{array}{c}\text { Unstandardized } \\
\text { Coefficients }\end{array}$} & $\begin{array}{c}\text { Standardized } \\
\text { coefficients }\end{array}$ & t & Sig. \\
\cline { 2 - 7 } & & $\mathrm{B}$ & Std. Error & Beta & & \\
\hline 1 & (Constant) & -11.371 & 10.581 & & -1.075 & 0.294 \\
& $\mathrm{X}_{1}$ & -0.703 & 5.762 & -0.016 & -0.122 & 0.904 \\
$\mathrm{X}_{2}$ & 2.342 & 0.822 & 0.179 & 2.849 & 0.009 \\
& $\mathrm{X}_{3}$ & 6.545 & 2.605 & 0.253 & 2.512 & 0.019 \\
& $\mathrm{X}_{4}$ & 2.054 & 0.699 & 0.158 & 2.938 & 0.007 \\
& $\mathrm{X}_{5}$ & 2.864 & 1.254 & 0.267 & 2.284 & 0.032 \\
& $\mathrm{X}_{6}$ & 5.468 & 2.610 & 0.305 & 2.095 & 0.047 \\
\hline
\end{tabular}


The conducted tests can be interpreted for each variable as follows:

a) Teaching length of geography teachers $\left(X_{1}\right)$

In the teaching length variable $\left(\mathrm{X}_{1}\right)$, it can be identified that the significant value of 0.904 is greater than the 0.05 probability. Therefore, it can be said that Ho is accepted, and $\mathrm{Ha}$ is rejected. Also, there is no positive and insignificant impact on the length of teaching $\left(\mathrm{X}_{1}\right)$ on the ability to construct HOTS-oriented assessment instruments.

b) Linearity of teacher education in tertiary institutions $\left(X_{2}\right)$

In this variable $\left(\mathrm{X}_{2}\right)$, it can be seen that 0.009 is smaller than the probability of 0.05. Therefore, it can be inferred that Ho is rejected, and $\mathrm{Ha}$ is accepted. This means the linearity of teacher education in tertiary institutions $\left(\mathrm{X}_{2}\right)$ has a positive and important impact on the ability to develop HOTS-oriented assessment instruments.

c) Background of teacher education $\left(\mathrm{X}_{3}\right)$

Regarding the education background variable $\left(X_{3}\right)$, it can be seen that the significant value 0.019 is smaller than the 0.05 probability. Therefore, it can be concluded that Ho is rejected and $\mathrm{Ha}$ is accepted. This means there is a positive and significant influence of the background variable $\left(\mathrm{X}_{3}\right)$ on the ability to develop HOTSoriented assessment instruments.

d) Teacher certification $\left(\mathrm{X}_{4}\right)$

In the certification variable $\left(\mathrm{X}_{4}\right)$, it can be seen that the significant value 0.007 is smaller than the 0.05 probability. Therefore, it can be concluded that Ho is rejected and $\mathrm{Ha}$ is accepted. This means there is a positive and significant influence of the certification variable $\left(\mathrm{X}_{4}\right)$ on the ability to develop HOTS-oriented assessment instruments.

e) Teacher training $\left(X_{5}\right)$

In this variable, it can be seen that the significant value 0.032 is smaller than the probability of 0.05 . Therefore, it can be concluded that Ho is rejected and Ha is accepted. This means there is a positive and significant effect of the teacher training variable $\left(\mathrm{X}_{5}\right)$ on the ability to develop HOTS-oriented assessment instruments.

f) Teacher's experience in making HOTS questions $\left(\mathrm{X}_{6}\right)$

In this variable, it can be seen that the significant value 0.047 is smaller than the 0.05 probability. Therefore, it can be concluded that Ho is rejected and $\mathrm{Ha}$ is accepted. This means there is a positive and significant influence of experience $\left(\mathrm{X}_{6}\right)$ on the ability to develop HOTS-oriented assessment instruments.

\subsection{Statistical Testing of Test $F$}

The results of the $\mathrm{F}$ test presented in Table 3 can be interpreted to indicate that the calculated $F$ value is 2.593 , with a significance of 0.046 . Meanwhile, the $F$ table value at the 
$95 \%$ confidence level $(\alpha=0.05)$ is 3.59 . Therefore, $F_{\text {count }}<F_{\text {table }}(2.593<3.59)$ and the significance level is $0.046<0.05$. This showed there was a linearity influence of teacher education in tertiary institutions $\left(\mathrm{X}_{2}\right)$, background $\left(\mathrm{X}_{3}\right)$, certification $\left(\mathrm{X}_{4}\right)$, training $\left(\mathrm{X}_{5}\right)$, and experience $\left(\mathrm{X}_{6}\right)$ on the ability to develop HOTS-oriented assessment instruments. At the same time, the length of teaching $\left(\mathrm{X}_{1}\right)$ has no effect on the ability to develop the assessment instruments.

Table 3. Multiple linear regression F Test analysis testing

\begin{tabular}{llccccc}
\hline \multirow{2}{*}{ Model } & $\begin{array}{c}\text { Sum of } \\
\text { Squares }\end{array}$ & df & Mean Square & F & Sig. \\
\cline { 2 - 6 } 1 & Regression & 134870.073 & 6 & 22478.345 & 2.593 & $0.046^{\mathrm{b}}$ \\
& 199402.594 & 23 & 8669.678 & & \\
Residual & 334272.667 & 29 & & & \\
Total & 33 &
\end{tabular}

Note $: \mathrm{b}=$ Predictors: (Constant), $\mathrm{X}_{6}, \mathrm{X}_{3}, \mathrm{X}_{4}, \mathrm{X}_{2}, \mathrm{X}_{5}, \mathrm{X}_{1}$

Results of the coefficient of determination (R-square) on the length of teaching $\left(\mathrm{X}_{1}\right)$, the linearity of education in tertiary institutions $\left(X_{2}\right)$, background $\left(X_{3}\right)$, certification $\left(X_{4}\right)$, training $\left(\mathrm{X}_{5}\right)$, and experience $\left(\mathrm{X}_{6}\right)$ on the ability to develop HOTS-oriented assessment instruments (Y) is explained in Table 4. The coefficient of determination value $\mathrm{R}=0.635$ means the relationship between teaching length, the linearity of education, background, certification, training, and experience is $63.5 \%$. This means the relationship is strong, and $36.5 \%$ is another factor.

Table 4. Determination coefficient test (R-square)

\begin{tabular}{ccccc}
\hline Model & R & R Square & Adjusted R Square & $\begin{array}{c}\text { Std. Error of the } \\
\text { Estimate }\end{array}$ \\
\hline $\mathbf{1}$ & $0.635^{\mathrm{a}}$ & 0.403 & 0.248 & 93.11111 \\
\hline
\end{tabular}

Note : a $=$ Predictors: (Constant), $\mathrm{X}_{6}, \mathrm{X}_{3}, \mathrm{X}_{4}, \mathrm{X}_{2}, \mathrm{X}_{5}, \mathrm{X}_{1}$

The ability of teachers is one of the factors that influence the accomplishment of learning and educational goals in schools. However, a teacher's competence does not stand alone but is influenced by other factors, including classroom assessments. The implementation of this assessment needs more knowledge to be effectively implemented. Eyal (2012) stated that (1) the need for teachers to evaluate literacy based on such quantitative data measures is disappearing, partially because it is based on conventional evaluation methods and because current disappearing, partially because it is teacher work, (2) teachers should have evaluation literacy, however for a variety of assessment forms. 
Stiggins (2002) defined "teacher assessment literacy," as a person who knows what methods are used to gather information about student achievement, conduct dialogue about effective assessment results, use rating scores, reports, and portfolios, and understands how to use assessment to improve student performance, motivate and involve them in the learning process. This is stated in the same line with Undang-Undang Nomor 14 (2005) that "teachers are professional educators with the main task of educating, teaching, guiding, directing, training, assessing, and evaluating students through formal, basic, and secondary education".

There are three simple reasons why assessment literacy is critical. Firstly, assessment is standard (as long as its not inherent) in most school systems. The teachers are estimated to spend $10 \%-50 \%$ of their working hours in assessment-related activities in some universities, and part of the budget is used for formal study (Macbeath et al., 2004). With much time and money spent on assessment, it is important to understand how evaluation decisions are made. The second reason why assessment literacy is important is that much literature needs to be studied. The last reason why assessment literacy is required is that it helps the teachers share class consequences with others.

This study focuses on the abilities of geography teachers in making HOTS-based assessment instruments in High School (SMA/MA). In line with Ahmad (2014), there are two opinions of teachers regarding education transition, namely positive and negative perceptions. The positive expectations promote a drive for improvement and creativity, while thenegative perceptions reflect the unpreparedness of teachers to make adjustments. The urgency of HOTS is connected to both teachers and students.

Lately, educational changes in many countries have shown a change from stressing low-level thinking skills (LOTS) to highlighting high-level thinking skills (HOTS) (Barak \& Dori, 2009). In Indonesia, more than a quarter of geography teachers outside Java are taught by non-geographic backgrounds teachers, leading to incorrect skills and knowledge (Gerber $\&$ Chuan, 2000). This greatly influences the use of HOTS-oriented assessment instruments in class. In addition to the linearity of education in tertiary institutions, this study also examines several factors that affect the ability to develop HOTS-oriented instruments that were carried out during research in SMA / MA with 30 subjects.

Several factors that affect the ability to develop HOTS-oriented questions include the linearity of teacher education in tertiary institutions $\left(\mathrm{X}_{2}\right)$. The results showed there are teachers whose education is not linear at PT with subjects that are taught in class. Infact, some still finds it difficult and lack understanding related to complex geography material, hence, the presentation of learning material in class is classified as general. This has an impact on the ability to develop HOTS-oriented questions. This is also supported by Prayitno 
(2019) which showed the level of education has a significant positive value on the professional competence of a teacher.

The second factor, namely the background of teacher education $\left(\mathrm{X}_{3}\right)$ affects the ability to develop HOTS-oriented questions. The field results showed there are teachers with linear education, especially in geography subjects, both undergraduate and graduate, which greatly affect the ability to develop HOTS questions. This is in line with Fadiarman (2018) which stated that the results of correlational analysis showed educational background and attitudes towards the teaching profession had a positive relationship with the pedagogic competence of social studies learning for junior high school teachers.

Furthermore, the third factor is related to the teacher certification factor $\left(\mathrm{X}_{4}\right)$.This factor may have a slight effect, but the existence of certification increases teacher motivation to become professionals, especially in the teaching, learning, and evaluation process in class. Therefore, when evaluating teacher in making questions, it needs to be in accordance with the demands of the national education system, which leads to training students in higher-order thinking. Research by Anggela (2015) showed high teacher motivation has a tendency to improve student learning outcomes. Also, the teachers with good motivation will always try to work as much as possible. This will encourage the achievement of optimal learning.

The fourth factor is the teacher training factor $\left(\mathrm{X}_{5}\right)$.This factor has a large contribution in influencing the ability to make HOTS questions. This is because based on observations in the field, some teachers who often attend training have good competence in planning and evaluating classroom learning. According to Widana (2020), a person will be motivated to work creatively as long as there is a good understanding of the concept. Therefore, understanding the assessment concept influences one's creativity in composing HOTS questions. This is supported by Rakib et al. (2016) which showed that training partially has a positive and significant effect on teacher professionalism. Research by Rahmawati (2015) also showed training is an activity that can have a positive and significant impact on professionalism at SMK Negeri 3 Palu. This is in line with research by Helmi (2018), which reported that teacher's training is to improve their professional competence.

Essentially, a 'teacher' is a person who provides educational programs, assesses student participation, and/or administers, provides consistency, and substantial leadership for educational programs. The standard of teachers has been said to be the number one effect on student success related to education. Although studies on what qualified teachers mean is often the topic of discussion, and there are certain quality results that are seldom debated (Barathimalar, 2014). Avargil et al. (2012) found that professional development teachers are assisted by students. This is seen from one teacher's answer that HOTS is important "because 
we face several problems that require knowledge, skills, and analysis so that we can overcome the problems of our daily life" The teacher used the term "we" not "students" or "them" in answer. This implies that not only students but even their teachers need HOTS. Also, teachers face very tough periods in the learning phase of adopting HOTS when it is not followed by daily socialization and government training (Retnawati et al., 2018).

The training carried out should be directly related to solving real problems and conditions in the classroom, as stated by Lang (1999). Also, Martinet (2001) stated that today, there is no finalized blueprint to explain the intentional growth of professional practice, but rather a collection of questions regarding the necessary expertise and skills accessible through training. The socialization and training quality is important to better understand the abilities and skills of HOTS through this activity (Lang, 1999; Martinet, 2001; Retnawati et al., 2018).

The fifth factor, namely the teacher's experience in making questions at the City/Regency, Provincial, and National levels. It is one of the factors that affect the ability to make HOTS questions. This is because from experience, the teacher can always learn to compile the questions in accordance with demands of the national education system which leads to higher order thinking skills. The results showed some teachers who had frequently made questions had skills both during the Mid-Semester Assessment (PTS), Final Semester Assessment (PAS), School Examination (US), Tryout at the City level / District, and at the provincial level. This is in line with (Iswandi \& Richardo, 2017) which showed there is a positive and significant influence of teaching experience on the variable of teacher professional ability in Senior High School Kartika XIV 1 Banda Aceh.

The five factors that make up this study variable are supported by the theory of Uno (2011) which showed teacher competence does not stand alone but is affected by educational context influences, teaching experience, and length variables. This is in line with research by Sahari (2018) which showed the independent variables including education, training and teaching experience have a significant influence on teacher professionalism. Furthermore, Ayuni (2016) reported that the excellent understanding and response were influenced by several factors, namely education level, scientific background, teaching length and load, participation in training, mastery of methods and media, reading intensity, as well as teacher work ethic.

In line with research by Widana (2020), getting an understanding of HOTS assessment can be done in various ways, including discussions in MGMP (Geography Teacher Working Group) forums, looking for reading material on internet media, or electronic books about HOTS assessment. Meanwhile, direct activities such as workshops, 
training, IHT (In House Training), or other forms can minimize challenges in competence development. Regarding this issue, the research team tries to respond and synchronize with situations in the field. Therefore, the factors influencing geography teachers in developing HOTS questions include a lack of training, especially for Senior High School (SMA/MA) teachers in Lampung Province, Indonesia.

\section{Conclusion}

The factors that influence the ability of geography teachers in developing HOTSoriented assessment instruments in this study indicate that the linearity of teacher education in universities, teacher education background, teacher certification, teacher training, and teacher experience in making HOTS questions on the ability of geography teachers in developing the HOTS-oriented learning outcome assessment instrument as evidenced by the t-test (partial) statistic shows that the length of teaching for geography teachers is (0.904), the linearity of teacher education in universities is (0.009), teacher education background is (0.019), teacher certification is (0.007), teacher training (0.032), and teacher experience in making HOTS questions (0.047). Things that need to be done for further research ideas are not only for research purposes, there needs to be a treatment for geography teachers to improve their ability to develop HOTS-oriented questions such as holding training or workshops.

\section{Conflict of Interest}

The Authors declare no conflict interest.

\section{References}

Afrian, R., Islami, Z. R., \& Mustika, F. (2018). Pembinaan Pembuatan Tes Buatan Guru (Soal) Mata Pelajaran Geografi SMA/MA Kota Langsa. Jurnal Vokasi - Politeknik Negeri Lhokseumawe, 1(2). https://doi.org/10.30811/vokasi.v1i2.687.

Ahmad, D. (2014). Understanding the 2013 Curriculum of English Teachers Through the Teachers' and Policymakers' Perspectives. International Journal of Enhanced Research in Educational Development, 2(4).

Anderson, L.W., \& Krathwohl, D.R. (2010). Kerangka landasan untuk pembelajaran, pengajaran, dan asesmen (terjemahan Agung Prihantoro). New York: Addition Wesley Longman.

Anggela, R. (2015). Hubungan antara Kompetensi Profesional Guru dan Motivasi Kerja Guru Dengan Prestasi di Kota Yogyakarta Tahun Ajaran 2012/2013. EDUKASI: Jurnal Pendidikan, 13(1). 
Artvinli, E. (2017). What is Innovative Geography Teaching? A Perspective from Geography Teachers. Journal of Education and Training Studies, 5(6). https://doi.org/10.11114/ jets.v5i6.2383.

Astuti, A. P., Aziz, A., Sumarti, S. S., \& Bharati, D. A. L. (2019). Preparing 21st Century Teachers: Implementation of 4C Character's Pre-Service Teacher through Teaching Practice. Journal of Physics: Conference Series, 1233(1). https://doi.org/10.1088/17426596/1233/1/012109.

Ati, A., Ruhimat, M., Yani, A. (2019). Pemahaman Guru Geografi Terhadap Konsep dan Pelaksanaan Penilaian Autentik di SMA Negeri Pulau Buton. Edusentris, 6(2), 59-68.

Avargil, S., Herscovitz, O., \& Dori, Y. J. (2012). Teaching Thinking Skills in Context-Based Learning: Teachers' Challenges and Assessment Knowledge. Journal of Science Education and Technology, 21(2), 207-225. https://doi.org/10.1007/s10956-011-9302-7.

Ayuni, F. N. (2016). Pemahaman Guru Terhadap Pendekatan Saintifik (Scientific Approach) Dalam Pembelajaran Geografi. Jurnal Geografi Gea, 15(2), 1-7. https://doi.org/10.17509/ gea.v15i2.3542.

Barak, M., \& Dori, Y. J. (2009). Enhancing higher order thinking skills among inservice science teachers via embedded assessment. Journal of Science Teacher Education, 20(5), 459-474. https://doi.org/10.1007/s10972-009-9141-z.

Barathimalar, A. (2014). The acceptance and problems faced by teachers in conducting higher order thinking skills. Doctoral Dissertation. Universiti Teknologi Malaysia.

Brookhart, S. M. (2010). How to Assess Higher-Order Thinking Skills in Your Classroom. Alexandria: ASCD.

Budiastini, N. P. D., Astawa, I. B. M., \& Sriartha, I. P. (2020). Kualitas Penerapan Asesmen Autentik Berbasis HOTS Guru Geografi SMA. Jurnal Pendidikan Geografi Undiksha, 8(2), 76. https://doi.org/10.23887/jjpg.v8i2.25352.

Chalkiadaki, A. (2018). A systematic literature review of 21 st century skills and competencies in primary education. International Journal of Instruction, 11(3), 1-16. https://doi.org /10.12973/iji.2018.1131a.

Jannah R., \& Ernawati, E. (2020). Analisis Level Kognitif Soal Ujian Akhir Semester (UAS) Geografi Kelas XI Semester Gasal SMA Negeri Se-Kota Pariaman Tahun Pelajaran 2019/2020 Berdasarkan Taksonomi Bloom Revisi Anderson. Jurnal Buana, 4(6).

Eyal, L. (2012). Digital assessment literacy-the core role of the teacher in a digital environment. Educational Technology and Society, 15(2), 37-49.

Fadiarman, F. (2018). Hubungan Latar Belakang Pendidikan dan Sikap Terhadap Profesi Guru dengan Kompetensi Pedagogik Pembelajaran IPS Guru SMP. Jurnal Geografi, Edukasi dan Lingkungan (JGEL), 2(1), 55-64. 
Fanani, M. Z. (2018). Strategi Pengembangan Soal HOTS Pada Kurikulum 2013. Edudeena, 2(1), 57-76. https://doi.org/10.30762/ed.v2i1.582.

Gerber, R., \& Chuan, G. K. (2000). Fieldwork in Geography: Reflections, Perspectives and Actions. Berlin : Springer Science and Business Media.

Helmi, D. (2018). Strategi Guru Geografi dalam Mengimplementasikan Standar Proses Permendikbud No 22 Tahun 2016 pada Pembelajaran Geografi di SMA Negeri Kabupaten Solok. Jurnal Kapita Selekta Geografi, 1(2), 141-148.

Heong, Y. M., Othman, W. B., Yunos, J. B. M., Kiong, T. T., Hassan, R. Bin, \& Mohamad, M. M. B. (2011). The Level of Marzano Higher Order Thinking Skillsamong Technical Education Students. International Journal of Social Science and Humanity, 1(2), 121125. https://doi.org/10.7763/ijssh.2011.v1.20.

Hong, C., \& Salika, E. (2011). Action Research in Teacher Education: Classroom Inquiry, Reflection, and Data-Driven Decision Making. Journal of Inquiry and Action in Education, 4(2), 1-17.

Ikhsan, F. A., Kurnianto, F. A., Apriyanto, B., \& Nurdin, E. A. (2017). Efforts to Improve the Competency of Professionalism Teacher in Jember Regency. Geosfera Indonesia, 1(1). https://doi.org/10.19184/geosi.v1i1.6191.

Iswandi, \& Richardo. (2017). Pengaruh latar belakang bidang studi, tingkat pendidikan dan pengalaman mengajar terhadap kemampuan profesional guru pada SMA Kartika XIV 1 Banda Aceh. Genta Mulia: Jurnal Ilmiah Pendidikan, 8(2).

King, F., Kreidler, C., Keefe, E. B., Copeland, S. R., Harste, J. C., Baten, C. E., Goodson, L., Faranak Rohani, M., Caladine, R., \& Lee, L. (2011). Higher Order Thinking Skills Definition, Teaching Strategies, Assessment, A publication of the Educational Services Program, now known as the Center for Advancement of Learning and Assessment. Tallahassee: FL: Florida State University.

Kurniawan, R. Y., \& Lestari, D. (2019). The Development Assessment Instruments of Higher Order Thinking Skills on Economic Subject. Dinamika Pendidikan, 14(1), 102-115. https://doi.org/10.15294/dp.v14i1.19226.

Lang, V. (1999). La professionnalisation des enseignants. Paris: Presses Universitaires de France.

Macbeath, J., Galton, M., Page, C., \& Edwards, J. (2004). A Life in Secondary Teaching : Finding Time for Learning. Cambdridge : University of Cambridge Faculty of Education.

Martinet, R. and G. (2001). Teacher Training. Quebec: Ministere de I'Education.

Mohamed, R., \& Lebar, O. (2017). Authentic assessment in assessing higher order thinking skills. International Journal of Academic Research in Business and Social Sciences, 7(2), 466-476. https://doi.org/10.6007/IJARBSS/v7-i2/2021. 
Munandar, A., Maryani, E., Rohmat, D., \& Ruhimat, M. (2020). Establishing the profesionalism of geography teacher through authentic assessment field study. International Journal of Instruction, 13(2), 797-818. https://doi.org/10.29333/iji.2020. 13254a.

Nitko, A. J. and Brookhart, S. M. (2011). Educational assessment of students. Boston: Pearson Education, Inc.

Noprinda, C. T., \& Soleh, S. M. (2019). Pengembangan Lembar Kerja Peserta Didik (LKPD) Berbasis Higher Order Thinking Skill (HOTS). Indonesian Journal of Science and Mathematics Education, 02(2), 168-176. https://doi.org/10.24042/ijsme.v2i2.4342.

Nugroho, F. A., \& Hastuti, H. (2019). Constraints of Geography Teacher of Sma N 1 Ngaglik in Developing the 2013 Curriculum Learning Devices in Sleman Regency. Geosfera Indonesia, 4(1). https://doi.org/10.19184/geosi.v4i1.9294.

OECD. (2019). What Students Know and Can Do: Indonesia. OECD, 1-10. Retrieved from https://www.oecd-ilibrary.org/education.

Rahmawati, S. (2015). Pengaruh Pelatihan, Pengalaman Mengajar dan Kompensasi terhadap Profesionalisme Guru di SMK Negeri 3 Palu. Katalogis, 3(12), 67-75.

Rakib, M., Rombe, A., \& Yunus, M. (2016). Pengaruh pelatihan dan pengalaman mengajar terhadap profesionalitas guru (Studi pada guru IPS terpadu yang memiliki latar belakang pendidikan dalam bidang Pendidikan Ekonomi). Jurnal Pemikiran Ilmiah Dan Pendidikan Administrasi Perkantoran, 3(2).

Retnawati, H., Djidu, H., Kartianom, Apino, E., \& Anazifa, R. D. (2018). Teachers' knowledge about higher-order thinking skills and its learning strategy. Problems of Education in the 21 st Century, 76(2), 215-230. https://doi.org/10.33225/pec/18.76.215.

Prayitno R., . (2019). Pengaruh Tingkat Pendidikan dan Pengalaman Mengajar terhadap Kompetensi Profesional Guru pada Mata Pelajaran IPS di SD Se kecamatan Buntu Batu Kabupaten Enrekang. Phinisi Integration Review, 2(1), 81-90.

Riduwan, D. (2012). Metode \& Teknik Menyusun Proposal. Bandung: Alfabeta.

Ruhimat, M. (2018). Kompetensi Pembuatan Instrumen Pengukuran Hasil Belajar oleh Guru IPS SMP di Kota Bandung. Lentera Pendidikan: Jurnal Ilmu Tarbiyah dan Keguruan, 21(2), 176. https://doi.org/10.24252/lp.2018v21n2i4.

Sahari, S. (2018). Pengaruh Pendidikan, Pelatihan, dan Pengalaman Mengajar terhadap Profesionalisme Guru di SMAN I Likupang. Jurnal Ilmiah Iqra', 9(1), 62-86. https://doi.org/10.30984/jii.v9i1.599.

Stiggins, R. (2002). Learning teams for assessment literacy. Journal of Staff Development, $30(4), 5-7$.

Sugandi, D., \& Somantri, L. (2018). Improving Geography Pre-Service Teachers' Understanding of Satellite Imagery Analysis Using Er Mapper Software With a Module. International Journal of Education, 11(1), 59. https://doi.org/10.17509/ije.v11i1.11162. 
Suhendro., Sugandi, Dede., \&, \& Ruhimat, M. (2020). Assesment Of Geography For 21 st Century. Jurnal Georafflesia, 5(1), 1-12.

Suherman, A. (2019). Kemampuan Guru Geografi dalam Memahami Paper And Pensil Test Jenis Multiple Choise pada Level Higher Order Thinking Skills (HOTS) di Kabupaten Bekasi. Thesis. Universitas Pendidikan Indonesia.

Suyanto, \& Jihad, A. (2013). Menjadi Guru Profesional, Strategi Meningkatkan dan Kualitas Guru di Era Global. Jakarta : Erlangga.

Undang-Undang Nomor 14 (2005). Tentang Guru dan Dosen. Jakarta : Presiden Republik Indonesia.

Uno, B. H., (2011). Teori Kinerja dan Pengukurannya. Cetakan pertama. Jakarta, Indonesia: Bumi Aksara.

Utaminingtyas, S. (2020). Implementasi Problem Solving Berorientasi Higher Order Thinking Skill (HOTS) Pada Pembelajaran IPS Sekolah Dasar Implementation Of Problem Solving Oriented Higher Order Thinking Skill (HOTS) In Social Learning Primary School. Jurnal Ilmiah Pendidikan Dasar, 7(2), 84-98. http://dx.doi.org/10.30659/pendas.7.2.84-98.

Wangid, M. N., Mustadi, A., Syamsudin, A., Hastuti, W. S., Perwitasari, N., Noor, A. F., Kusrini, E., \& Prihandoko, Y. (2020). Pelatihan Pembelajaran dan Penilaian Berbasis HOTS Bagi Guru SD Se-Kecamatan Mantrijeron Kota Yogyakarta. PengabdianMu: Jurnal Ilmiah Pengabdian Kepada Masyarakat, 5(4), 394-403. https://doi.org/10.33084 /pengabdianmu.v5i4.1197.

Wantoro, J., Sutama, S., Zuhriah, S., \& Hafida, S. H. N. (2019). Pengembangan Instrumen Penilaian Pendidikan Profesi Guru Sekolah Dasar Bebasis HOTS. Profesi Pendidikan Dasar, 1(1), 11-20. https://doi.org/10.23917/ppd.v1i1.8453.

Widana, I. W. (2020). Pengaruh Pemahaman Konsep Asemen HOTS terhadap Kemampuan Guru Matematika SMA/SMK Menyusun Soal HOTS. Jurnal Emasains: Jurnal Edukasi Matematika dan Sains, 9(1), 66-75. 